\title{
Association between field liming and the epidemic of Type 1 diabetes
}

\author{
Seppo K Junnila* \\ Health Centre of the Town of Haapajärvi, 85800 Haapajärvi, Finland
}

Received: October 10, 2017

Accepted: November 29, 2017 Online Published: December 3, 2017

DOI: $10.5430 /$ jer.v4n1p27

URL: https://doi.org/10.5430/jer.v4n1p27

\begin{abstract}
Zinc is an essential nutrient for mammals. Zinc has only one oxidation state $\mathrm{Zn}^{2+}$ but it has many coordination states, which can alter without demanding energy. Coordination states depend on prevailing $\mathrm{pH}$. In soils the coordination state changes from octahedral (nonphysiologic) form to tetrahedral (physiologic) form when $\mathrm{pH}$ rises to about 6.5. Weathering processes of common soil mineral mica are also $\mathrm{pH}$ dependent. Large scale argricultural field liming began from 1950's onward in the Western Countries and since that time the incidence of Type 1 diabetes (T1D) began to increase in the Western Countries. Liming elevates soil $\mathrm{pH}$ often near 6.5 and favours mosaic mica-vermiculite nanoparticle formation in which vermiculite corner binds zinc in tetrahedral (physiological) coordination state. In this $\mathrm{pH}$ mica corner remains in native form and offers the plane for soluble pMHC molecule (binded with antigenic beta-cell specific self peptide) to adhere on mica and as a consequence to trigger the activation of autoreactive CD4 and/or CD8 T cells. Beta-cell specific autoantigens are released because abundant zinc derived from endocytosed zinc-mica-vermiculite particles in lysosomes leads to incresed beta-cell apoptosis, also the physiological neonatal beta-cell mass remodeling enhance beta-cell specific auto-antigen release. Furthermore enterovirusinfections during first years of life are common and can release beta-cell specific auto-antigens. The probable disease mechanism is dealt with this review article.
\end{abstract}

Key Words: Soil liming, Zinc coordination states, Non-conventional T cell activation, Natural nanoparticles

\section{INTRODUCTION}

Type 1 diabetes (T1D) is an autoimmune disease, in which the production of insulin by pancreatic islet beta-cells has stopped. Beta-cells are destroyed by the attack of own immune system. T1D breaks out in some of children (before the age of 15 years), who has a genetic susceptibility for disease. However only 1 of 14-20 with HLA-conferred susceptibility progress to the clinical disease. ${ }^{[1]}$ About twelve per cent of newborns in Finnish DIPP study carried HLA II susceptibility genes for T1D. ${ }^{[2]}$

The incidence of T1D has increased since 1950's. Before 1950's T1D was uncommon but known disease, the incidence of which was some 2-7/100,000/year (in the sequel the incidence numbers are always per 100,000 per year). Nowadays T1D incidence is about $20,{ }^{[3]}$ in Finland even $65 .{ }^{[4]}$ Globally there is over 350 fold difference in the incidence between countries. ${ }^{[3]}$ It seems that the incidence of T1D in Finland has ceased to increase during last years, ${ }^{[4]}$ the same is true also in other high incidence countries. ${ }^{[3]}$ On the other hand the incidence is increasing in lower incidence countries. Something in our environment must be changed, because the heredity cannot change in this time period.

*Correspondence: Seppo K Junnila; Email: seppo.junnila@pp.inet.fi; Address: Health Centre of the Town of Haapajärvi, 85800 Haapajärvi, Finland. 
This environment change cannot be virus or bacteria because there is e.g. six fold gradient in boundary between Finland and Russian Karelia. The populations in both side of the border are genetically homogenous. Sosioeconomic circumstances are quite different in Finland and in Russian Karelia. ${ }^{[5]}$ Also agricultural practice are quite different between Finland and Russian Karelia. When field liming practice is in common use in Finland, no such practice is in use in Russian Karelia (Harri Huhta, personal communication).

\section{CONTEMPORARY INCREASE OF T1D INCI- DENCE AND FIELD LIMING}

In Finland the soils are acidic and therefore farmers began field liming in 1950's. ${ }^{[6]}$ Average field $\mathrm{pH}$ has rosen from 5.50 (1955-60) to 5.87 (1986-90), thereafter field $\mathrm{pH}$ has fallen to 5.72 (1966-2000). In top years lime was used $1400 \times 10^{6} \mathrm{~kg} /$ year (1984-85), thereafter (1996-97) lime quantity has fallen to $500 \times 10^{6} \mathrm{~kg} /$ year. $^{[7]}$

In the year 1953 the incidence of T1D was 12 and reached the peak in the year 2006 being 65 . Thereafter the incidence has had the lowering diatheses. ${ }^{[4]}$ It seems that the rise and the fall in the incidence of T1D are a bit backward compared to the liming practice.

Association between liming and T1D can be found around the world. In the Brazil the huge Cerrado (Brazil's savannah) was changed to a farm field from 1973 on. The first step was massive liming which is continuing to day. ${ }^{[8,9]}$ The incidence of T1D in the Cerrado area has increased from 2.82 in the year 1987 to 18.4 in the year 2002, a 6.5 fold increase. ${ }^{[10]}$

Incidense of T1D is very high and increasing in the Canadian Province Newfoundland and Labrador (NL) over the period 1987-2010. Incidence increased by a factor of $1.03 \%$ per year over 24 years and was 49.9 in the period 2007-2010, it is one of the highest reported worldwide. ${ }^{[11]}$ Cropland liming in Canada is common only in the Provinces of NL and Prince Edvard Island. In the year 2010 lime was used on only $1.1 \%$ of the whole Canadian cropland area. In contrast to this, $19.5 \%$ of cropland area was limed in NL. ${ }^{[12]}$

\section{EFFECTS OF SOIL PH ON ZINC SPECIA- TION}

Zinc is ubiquitous metal in soils and waters. $\mathrm{Zn}^{2+}$ has a strong tendency to complexate with various ligands in soils and waters so that the true free $\mathrm{Zn}^{2+}$ concentrations are in picomolar level. ${ }^{[13]} \mathrm{Zn}$ has only one oxidation states $\mathrm{Zn}^{2+}$. Zinc atom has two main coordination states, tetrahedral and octahedral. Switching from octahedral to tetrahedral and vice versa does not demand energy but depends only on surrounding atoms and their geometry and prevailing $\mathrm{pH} .{ }^{[14]} \mathrm{In}$ proteins the ligand forming atoms are oxygen, nitrogen, and sulfur atoms from the side chains of aminoacids histidine, glutamate, aspartate and cysteine. ${ }^{[15]}$

In soil environment $\mathrm{Zn}^{2+}$ speciation (complexation with mineral particles in octahedral/tetrahedral manner) depends strongly on soil $\mathrm{pH}$. In the acid $\mathrm{pH}(<6.5)$ predominantly octahedral coordination prevails and in higher $\mathrm{pH}(>6.5)$ tetrahedral coordination prevails. Zinc containing minerals, most common in soils $\mathrm{ZnS}$ (sphalerite), weather slowly and depending on prevailing $\mathrm{pH}$, neoformed particulate zinc complexes contain octahedral and/or tetrahedral zinc depending on $\mathrm{pH}$. In the soil sample (topsoil, mixed clay mineralogy, Northern Switzerland), whose $\mathrm{pH}$ was $6.5,43 \%-45 \%$ from the added $\mathrm{ZnS}$ was tetrahedrally coordinated after 4 years of incubation. It could not be found any tetrahedrally coordinated $\mathrm{Zn}$ in the soil sample (topsoil, clay loam texture, North Carolina, USA), whose $\mathrm{pH}$ was 5.0, after 4 yers of incubation. In the soil sample, whose $\mathrm{pH}$ was 7.7 (very high), (topsoil, calcareous, high organic matter content, Northern Switzerland), $13 \%$ from added $\mathrm{Zn}$ was tetrahedrallycoordinated after 4 years of incubation. ${ }^{[16]}$ Soils contain various zinc sorbents. One of the most effective zinc sorbent is a clay mineral vermiculite. Zinc sorbed on vermiculite is not sorbed very tightly so zinc can be released from vermiculite by various zinc ligands e.g. human zinc transporters (proteins). Zinc sorbed on manganese oxide, also effective zinc sorbent, zinc sits very tightly and cannot released by organic zinc ligands. ${ }^{[17]}$ Intrestingly in high-risk T1D country Finland, the highest T1D-risk areas are convergent to the areas to whom it is typical the low manganese concentration in the stream waters. ${ }^{[18]}$

Pure vermiculite is only rarely found in soils. As a rule mosaic particles (scales) in which vermiculite and mica are intergrown are found in soils. Mica is very common soil mineral. Mica (aluminosilicate) is one of numerous silica polymorphs, which includes e.g. quartz, asbestos, and amorphous silica. In litterature the term silicate is often used as synonym for silica polymorphs. Pure mica nanoparticles has immunostimulatory effects and it functions as superantigen in T cell activation. Mica is sheet mineral, the basal sheet being in the scale of $1 \mathrm{~nm}$ in thickness. Mica sheet is very flexible and glossy. ${ }^{[19,20]}$

Limed soils contains flat particles (mikro-nano scale) in which one corner consists of flat flexible, glossy mica and the other corner consists of vermiculite and to it sorbed tetrahedrally (bioavailable) zinc. Zinc functions as ligand that guides the particle to islet environment because beta-cell is the great zinc user. ${ }^{[21]}$ Orally administered mica nanoparticles can cause suppressive effects on subcutaneously trans- 
planted human breast cancer cell growth in mouse xenograft model. This indicates that mica nanoparticles are absorbed from gut to circulation and from circulation to tumor enviroment at least in mice. ${ }^{[22]}$ These mosaic particles are introduced into human through water and/or food and/or breathing air.

\section{ROLE OF ZINC IN T CELL ACTIVATION}

Zinc is a micronutrient needed for cell activities including cell growth, differentiation and survival. There is growing evidence that zinc functions as a signal molecule in many signaling cascades. The importance of zinc for human physiology is supported by the findings that approximately $10 \%$ of human genome is encoding zinc-proteins. Because $\mathrm{Zn}$ is so essential as a signaling molecule, its homeostasis is tightly regulated by $\mathrm{Zn}$ transporters and intracellular metallothioneins (specific zinc binding cysteine rich proteins). At present it is known 24 various $\mathrm{Zn}$ transporters, of which 14 mediate inward (into cytoplasm) Zn transport (ZIP family) and 10 mediate outward (from cytoplasm into extracellular space or into intracellular organelles) $\mathrm{Zn}$ transport (ZnT family). ${ }^{[23]}$

In $T$ cell activation dendritic cells or other antigen presenting cells (APC) form a contact with T cell, forming a kind of an immunologic synapse. In this contact peptide containing class I and/or class II MHC molecule (pMHC) on the surface of APC contacts cognate T cell receptor (TCR). TCR is activated and naive CD4+ or CD8+ T cell differentiates into e.g. CD4+ Th1 memory cell or CD8+ memory cytotoxic T cell. If APC presents autoantigenic peptide (self peptide) in its MHC I or II, activated T cells can bring about an autoimmune disease. Proper T cell activation depends also on suitable cytokine milieu.

When in contact with TCR (forming immunologic synapse) and $\mathrm{T}$ cell membrane, APC decreases its intracellular zinc cocentration by zinc exporters, mainly $\mathrm{ZnT} 1$ and $\mathrm{T}$ cells increase intracellular zinc concentration by zinc importers ZIP6 and ZIP8. Perhaps the contact between APC and T cell resembles the nervous system synapse and zinc transfers directly from APC to T cell through a direct cell-cell contact, through a direct ZnT1-ZIP6 contact and ZnT1-ZIP8 contact. Zinc concentration increases particularly in the subsynaptic region of $\mathrm{T}$ cell (a kind of zinc wave). ${ }^{[23-25]} \mathrm{Up}$ to date experiments concerning the effects of zinc on immune activation has been done with Zinc salts (free $\mathrm{Zn}^{2+}$ ion). No one studies done with complexated particle bound zinc cannot be found in literature.

\section{SuPPOSED MECHANISM OF T CELL AC- TIVATION BY ISLET-SPECIFIC AUTOANTI- GENS IN T1D}

Most healthy individuals have beta-cell specific autoreactive $\mathrm{T}$ cells in their peripheral blood (central memory $\mathrm{T}$ cells). In healthy individuals Treg cells are thought to prevent the further activation of these central memory $\mathrm{T}$ cells to effector memory CD4+ T cells or effector memory cytotoxic CD8+ $\mathrm{T}$ cells. ${ }^{[26,27]} \mathrm{T} 1 \mathrm{D}$ development requires both beta-cell specific further activated CD4+ T cells and beta-cell specific further activated CD8+ T cells. ${ }^{[28]}$ This kind of beta-cell specific $\mathrm{T}$ cell activation must occur in a something unexpected way. Because the activation of CD8+ T cell needs the help of activated CD4+ T cell, probably the first fateful event is irrelevant central memory CD4+ $\mathrm{T}$ cell futher activation to effector memory CD4+ T cell. ${ }^{[29]}$

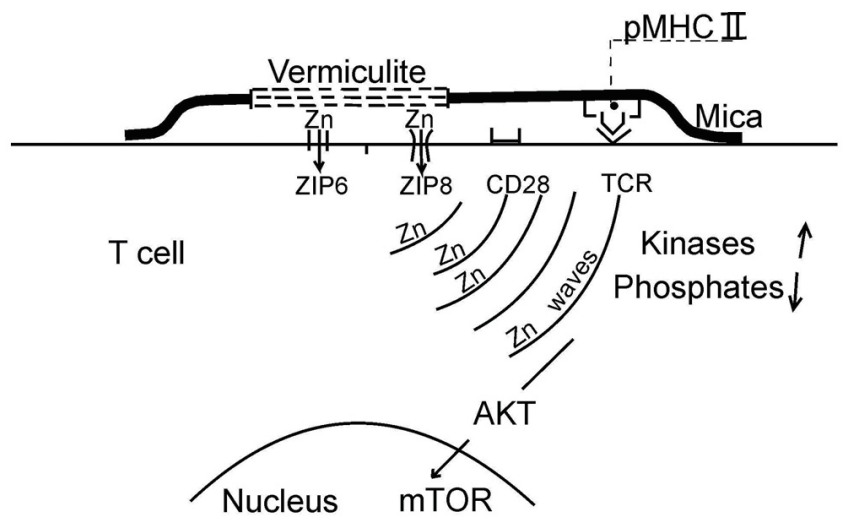

Figure 1. Proposed mechanism of atypical central memory $\mathrm{CD} 4+\mathrm{T}$ cell further activation in pancreatic islet environment

CD4+ central-memory $T$ cell in pancreatic islet enviroment. T cell adherent mica-vermiculite has on its mica corner beta cell specific peptide + MHC II molecule complex (pMHC II) which triggers TCR. Zinc transporters ZIP6 and ZIP8 acquire zinc from vermiculite corner of mica-vermiculite scale. Zn concentration in T cell increases especially in TCR subregion. The net effect of increased $\mathrm{Zn}$ concentration is the activation of co-stimulatory signaling (CD28) pathway kinases and the inhibition of co-inhibitory signaling pathway phosphatases. As an example is one of the stimulatory pathway originating from CD28 co-receptor activation. AKT and mTOR are downstream kinases. Zn functions as mitogen. The end result is effector memory $C D 4+T$ cell.

The contact between APC and CD4+ T cell is not always necessary for the activation of CD4+ T cell. On glossy surface-anchored antigenic peptide bound soluble MHC II molecule can activate the same antigenic peptide specific CD4+ T cell (see Figure 1). Glossy surfaces can be presented by e.g. plastic, glass and mica. ${ }^{[30,31]}$ In successful 
CD4+ T cell activation, the activation of various co-receptors (co-signaling receptors) on $\mathrm{T}$ cell is also mandatory. One important co-stimulatory receptor is CD28, which is important in metabolic change of activated T cell. Naive or central memory CD4+ T cell can not be succesfully activated into effector-memory $\mathrm{T}$ cell without changeing its metabolism from oxidative metabolism to aerobic glycolysis. ${ }^{[32]}$

The strong zinc influx (zinc wave) in context of TCR activation may result in down-stream events similar to CD28 co-receptor signaling (metabolic change in T cell). In downstream events of CD28 signaling various kinase enzymes are activated and phosphatase enzymes are inhibited. Zinc promotes kinase activity and inhibits phosphatase activity. ${ }^{[24,33]}$

In the neonatal period there is enhanced beta-cell remodelling associated with beta-cell apoptosis and enhanced beta-cell specific antigen release. ${ }^{[34]}$ This may trigger T1D by previously described manner. The known T1D associated HLA risk haplotypes may preferentially bind some auto-antigens released in beta cell apoptosis. ${ }^{[35]}$

Enterovirus infections are common in children within first years of life. Many enteroviruses are pancreotropic and human islet cells express coxsackie virus receptor. Enterovirusinfection can cause islet cell cytolysis which releases isletspecific antigens within islet milieu. Enterovirus infection before the age of six months seems to be especially dangerous and also after the age of two years. ${ }^{[2]}$

Lysosomal dysfunction also increase antigen abundance. Lysosomes clean a cell from dysfunctional cytoplasmic organelles and damaged proteins by hydrolytic enzymes. Functional cysteine cathepsins $\mathrm{B}$ and $\mathrm{L}$ have a central role on this cleaning (called autophagy). Inhibition of cathepsin B and $\mathrm{L}$ enhances beta-cell apoptosis and antigen release in the beta-cell milieu. ${ }^{[36]}$ Interestingly cathepsins B and L are very zinc sensitive enzymes. Inhibitory zinc cocentration for these enzymes is 0.1-1 mikroM. When lysosomes engulf zinc sorbed vermiculite particles, lysosomal zinc concentration may exceed this concentration. ${ }^{[37]}$

\section{Conclusion}

The incidence of T1D began to increase from 1950's on in Western developed countries. Nowadays the incidence of
T1D is increasing most rapidly in low incidence countries. Different environmental factors and changes is proposed to be behind this development e.g. enterovirus infections and hygiene hypothesis.

T1D is an autoimmune disease and demands an external trigger to break out. Soil liming that began on a large scale since 1950's is a clear environmental change, soil $\mathrm{pH}$ rises and mica weathering in mica-vermiculite axis changes ${ }^{[38]}$ and zinc coordination in mica-vermiculite nanoparticles changes from octahedral to tetrahedral (bioavailable). These nanoparticles can function as autoimmunity trigger in T1D.

Silica based engineered nanoparticles have many biomedical applications e.g. drug delivery and gene delivery. The surface of silica based nanoparticles can be doped with various atoms or molecules that directs nanoparticles to required tissue or cell type. Up to date applications of silica based nanoparticles have restricted to preclinical studies since potential adverse effects, mainly inflammation. ${ }^{[39]}$ It is still very challenging to detect and characterize nanoparticles from environmental samples. The association between liming and T1D is therefore difficult to prove by present detection methods. Development in analytical methods is crucial to prove this association impressively. ${ }^{[40]}$

Besides soils, also lakes and rivers and river catchments have been limed to mitigate lake and river acidification in many countries e.g. in Sweden, Norway and Scotland. The largescale federal liming program in Sweden was initiated in 1977 to mitigate lake acidification. ${ }^{[41]}$ A significant geographical variation in incidence rate of T1D between 1977-1995 was found between the municipalities in south east Sweden. In the same region it was also earlier shown space-time clusters in T1D incidence. ${ }^{[42]}$ Investigation which take account of liming history (agricultural if possible and lakes, rivers and catchments) and T1D incidence spatial clustering in that region should be desirable.

\section{CONFLiCTS OF INTEREST Disclosure}

The author declares that there is no conflict of interest regarding the publication of this paper.

\section{REFERENCES}

[1] Knip M, Veijola R, Virtanen SM, et al. Environmental triggers and determinants of type 1 diabetes. Diabetes. 2005; 54: 125-36. https://doi.org/10.2337/diabetes.54.suppl_2.S125

[2] Honkanen H, Oikarinen S, Nurminen N, et al. Detection of enteroviruses in stools precedes islet autoimmunity by several months: possible evidence for slowly operating mechanism in virus-induced autoimmunity. Diabetologia. 2017; 60: 424-431. PMid:28070615. https://doi.org/10.1007/s00125-016-4177-z

[3] Gale EAM. The rise of childhood type 1 diabetes in the 20th century. Diabetes. 2002; 51: 3353-61. https ://doi.org/10.2337/diab etes. 51.12 .3353 
[4] Harjutsalo V, Sund R, Knip M, et al. Incidence of type1 diabetes in Finland. JAMA. 2013; 310(4): 427-28. PMid:23917294. https://doi.org/10.1001/jama.2013.8399

[5] Kondrashova A, Reunanen A, Romanov A, et al. A six-fold gradient in the incidence of type 1 diabetes at the eastern border of Finland. Ann Med. 2005; 37(1): 67-72. PMid:15902849. https: //doi.org/10.1080/07853890410018952

[6] Uusitalo R, Salo R. Investigated soil-safe food (article in finnish). 2002; ISBN 951-729-695-9.

[7] Myyrä S. Decreasing trend in agricultural field liming (article in finnish). Koetoiminta ja käytäntö. 2004; 61(4): 11-12.

[8] The miracle of the cerrado. The Economist. 2010.

[9] Bernoux M, Volkoff B, da Conceicao M, et al. CO2 emissions from liming of agricultural soils in Brazil. Global Biogeochemical Cycles. 2003; 17: 1049.

[10] Negrato CA, Dias JP, Teixeira MF, et al. Temporal trends in incidence of type 1 diabetes between 1986 and 2006 in Brazil. J Endocrinol Invest. 2010; 33: 373-7. PMid:19620822. https://doi .org/10.1 007/BF03346606

[11] Newhook LA, Penney S, Fiander J, et al. Recent incidence of type 1 diabetes mellitus in children 0-14 years in Newfoundland and Labrador, Canada climbs to over 45/100,000: a retrospective time trend study. BMC Res Notes. 2012; 5: 628. PMid:23146327. https://doi.org/10.1186/1756-0500-5-628

[12] Dorff E, Beaulieu MS. Feeding the soil puts food on your plate. Statistics Canada, Census of Agriculture. 2015.

[13] Hoffmann SR, Shafer MM, Armstrong DE. Strong colloidal and dissolved organic ligands binding copper and zinc in rivers. Environ Sci Technol. 2007; 15: 6996-7002.

[14] Roberts DR, Ford RG, Sparks DL. Kinetics and mechanisms of Zn complexation on metal oxides using EXAFS spectroscopy. Journal of Colloid and Interface Science. 2003; 263: 364-376. https: //doi.org/10.1016/S0021-9797(03)00281-9

[15] Krezel A, Maret W. The biological inorganic chemistry of zinc ions. Arch Biochem Biophys. 2016; 611: 3-19. PMid:27117234. https://doi.org/10.1016/j.abb.2016.04.010

[16] Voegelin A, Jacquat O, Barmettler K, et al. Time-dependent changes of zinc speciation in four soils contaminated with zincite or sphalerite. Environ Sci Technol. 2011; 45: 255-261. PMid:21142002. https://doi.org/10.1021/es101189d

[17] Covelo EF, Vega FA, Andrade ML. Competitive sorption and desorption of heavy metals by individual soil components. J Hazard Mater. 2007: 140: 308-15. PMid:17049729. https://doi.org/10.101 $6 / j \cdot j$ hazmat. 2006.09.018

[18] Junnila SK. Type 1 diabetes epidemic in Finland is triggered by zinccontainig amorphous silica nanoparticles. Medical Hypotheses. 2015; 84: 336-340. PMid:25659493. https://doi.org/10.1016/j .me hy. 2015.01.021

[19] Hillier S, Marwa EMM, Rice CM. On the mechanism of exfoliation of "vermiculite". Clay Minerals. 2013; 48: 563-82. https : //doi.org/10.1180/claymin. 2013.048.4.01

[20] Jung M, Shin MK, Jung YK, et al. Modulation of macrophage activities in proliferation, lysosome and phagosome by the nonspecific immunostimulator, mica. PloS One. 2015; 10(2): e0117838. PMid:25668030. https://doi.org/10.1371/journal.pone.0 117838

[21] Li YV. Zinc and insulin in pancreatic beta-cells. Endocrine. 2014; 45: 178-89. PMid:23979673. https ://doi .org/10.1007/s120 20-013-0032-x

[22] Kang TW, Kim HS, Lee BNC, et al. Mica nanoparticle, STB-HO eliminates the human breast carcinoma cells by regulating the interac- tion of tumor with its immune microenvironment. Scientific Reports. 2015; 5: article number 17515 .

[23] Hojyo S, Fukada T. Roles of zinc sinaling in the immune system. Journal of Immunological Research. 2016; Article ID 6762343.

[24] Yu M, Lee WW, Tomar D, et al. Regulation of T cell receptor sinaling by activation-induced zinc influx. J Exp Med. 2011; 208: 775-85. PMid:21422171. https://doi.org/10.1084/jem. 20100031

[25] Costello LC, Fenselau CC, Franklin RB. Evidence for operation of the direct zinc ligand exhange mechanism for trafficking, transport and reactivity of zinc in mammalian cells. J Inorg Biochem. 2011; 105: 589-99. PMid:21440525. https://doi.org/10.1016/j.ji norgbio.2011.02.002

[26] Danke NA, Koelle DM, Yee C, et al. Autorective T cells in healthy individuals. J Immunol. 2004; 172: 5967-72. https ://doi .org/ 10.4049/jimmunol.172.10.5967

[27] Skowera A, Ladell K, McLaren JE, et al. Beta-cell-specific CD8 $\mathrm{T}$ cell phenotype in type 1 diabetes reflects chronic autoantigen exposure. Diabetes. 2015; 64: 916-925. PMid:25249579. https : //doi.org/10.2337/db14-0332

[28] Phillips JM, Parish NM, Raine T, et al. Type 1 diabetes development requires both CD4+ and CD8+ $\mathrm{T}$ cells and can be reversed by non-depleting antibodies targeting both $\mathrm{T}$ cell populations. Rev Diabet Stud. 2009; 6: 97-103. PMid:19806239. https : //doi.org/10.1900/RDS.2009.6.97

[29] Bourgeous C, Tanchot C. CD4 T cells are required for CD8 T cell memory generation. Eur J Immunol. 2003; 33: 3225-3231. PMid:14635030. https://doi.org/10.1002/eji. 200324576

[30] Nicolau DV, Watson GS, Cahill C, et al. Actin adsorbed on HOPG and mica substrates: characterization and manipulation by atomic force microscopy. NSTI-Nanotech. 2004; 1: 103-105.

[31] Ma Z, Sharp KA, Janmey PA, et al. Surface-anchored monomeric agonist pMHCs alone trigger TCR with high sensitivity. PloSBiol. 2008; 6: e43. PMid:18303949. https://doi.org/10.1371/jour nal.pbio. 0060043

[32] Frauwirth KA, Riley JL, Harris MH, et al. The CD28 signaling pathway regulates glucose metabolism. Immunity. 2002; 16: 769-77. https://doi.org/10.1016/S1074-7613(02)00323-0

[33] Arora G, Sajid A, Arulanandh MD, et al. Zinc regulates the activity of kinase-phosphatase pair (BasPrkC/BasPrpC) in Basillus anthracis. Biometals. 2013; 26: 715-30. PMid:23793375. https: //doi.org/10.1007/s10534-013-9646-y

[34] Trudeau JD, Dutz JP, Arany E, et al. Neonatal beta-cell apoptosis: a trigger for autoimmune diabetes? Diabetes. 2000; 49: 1-7.

[35] Bach JM, Otto H, Nepom GT, et al. High affinity presentation of an autoantigenic peptide in type 1 diabetes by an HLA class II protein encoded in a haplotype protecting from disease. J Autoimmun. 1997; 10: 375-86. PMid:9237801. https://doi.org/10.1006/jaut.1 997.0143

[36] Jung M, Lee J, Seo HY, et al. Cathepsin inhibition-induced lysosomal dysfunction enhances pancreatic beta-cell apoptosis in high glucose. PloS One. 2015; 10: e0116972.

[37] Lockwood TD. Lysosomal metal, redox and proton cycles influencing the CysHis cathepsin reaction. Metallomics. 2013; 5: 110-124. PMid:23302864. https://doi.org/10.1039/c2mt20156a

[38] Acker JG, Bricker OP. The influence of $\mathrm{pH}$ on biotite dissolution and alteration kinetics at low temperature. Geochimica et Cosmochimica Acta. 1992; 56: 3073-92. https://doi .org/10.1016/0016-703 7 (92) 90290-Y

[39] Li T, Jianjun C. Nonporous silica nanoparticles for nanomedicine application. Nano Today. 2013; 8: 290-312. PMid:23997809. https : //doi.org/10.1016/j.nantod.2013.04.007 
[40] Tiede K, Boxall ABAB, Tear SP, et al. Detection and characterization of engineered nanoparticles in food and the environment. Food Additives \& Contaminants: Part A. 2008; 25: 795-821. PMid: 18569000. https://doi.org/10.1080/02652030802007553

[41] Sverdrup HU, Warfvinge PG. What is left for researchers in liming? A critical review of state-of-art acidification miotigation. Lake an
Reservoir Management. 1988; 4: 87-97. https://doi.org/10.1 080/07438148809354383

[42] Samuelsson U, Löfman O. Geographical mapping of type 1 diabetes in children and adolescents in south east Sweden. J Epidemiol Community Health. 2004; 58: 388-392. https ://doi.org/10.1136/ jech.2002.004135 